\title{
EFEKTIVITAS METODE TRANSFEKSI DALAM TRANSFER GEN PADA ZIGOT IKAN CUPANG ALAM (WILD BETTA), Betta imbellis
}

\author{
Anjang Bangun Prasetio, Eni Kusrini, Ruby Vidia Kusumah, \\ Sawung Cindelaras, dan Siti Murniasih \\ Balai Penelitian dan Pengembangan Budidaya Ikan Hias \\ Jl. Perikanan No. 13, Pancoran Mas, Depok 16436 \\ E-mail:azamhafidz@yahoo.co.id
}

(Naskah diterima: 7 Januari 2013; Disetujui publikasi: 2 April 2013)

\begin{abstract}
ABSTRAK
Transfeksi merupakan salah satu metode transfer gen (transgenesis) yang tepat diaplikasikan pada cupang alam (wild betta), Betta imbellis dikarenakan pemijahannya yang alami dan sulit untuk dilakukan stimulasi. Penelitian yang terkait dengan upaya peningkatan kualitas warna ikan cupang alam ini bertujuan untuk melihat efektivitas metode transfeksi dalam penyisipan gen asing pada zigot B. imbellis. Analisis laboratorium dan proses pemeliharaan ikan dilaksanakan di Balai Penelitian dan Pengembangan Budidaya Ikan Hias serta Balai Penelitian Pemuliaan Ikan, selama 6 bulan. Calon induk B. imbellis diseleksi dan dipijahkan dengan perbandingan 1@\&: $1 \mathrm{~B} \&$, selanjutnya dilakukan transfeksi pada telur yang telah dibuahi, sebagian kecil diambil untuk isolasi DNA dan di-PCR. Gen asing yang digunakan untuk perlakuan adalah Green Flourenscent Protein (GFP) 1:1 dan 3:1 serta Red Flourescent Protein (RFP) 1:1 dan 3:1 dengan jumlah ulangan masing-masing sebanyak 6 kali. Sebagai kontrol, ditambahkan juga perlakuan non tranfeksi (non transgenik) yaitu tanpa penyisipan gen GFP maupun RFP. Pengamatan dilakukan sejak perkembangan zigot mulai dari penghitungan derajat penetasan (HR) dan sintasan larva (SR). Hasil penelitian menunjukkan bahwa setelah dilakukan transfeksi tidak memperlihatkan pola yang jelas dari setiap perlakuan, namun secara umum tidak berbeda signifikan dengan kontrol non transgenik. PCR pada embrio dan larva menunjukkan hasil positif di mana DNA teramplifikasi pada ukuran sekitar 0,6 kb untuk beberapa ulangan. Dari hasil yang diperoleh ini dapat ditarik kesimpulan bahwa metode transfeksi efektif digunakan untuk transfer gen ikan cupang alam, wild betta (Betta imbellis).
\end{abstract}

KATA KUNCI: Betta imbellis, transfer gen, transfeksi

ABSTRACT: Effectiveness of transfection method on gene transfer in wild Betta (Betta imbellis) zygote. By: Anjang Bangun Prasetio, Eni Kusrini, Ruby Vidia Kusumah, Sawung Cindelaras, and Siti Murniasih

Transfection is one of the proper method that was applied to the Betta imbellis because fishes spawn naturally and difficult to stimulate artificially. The research objective was to evaluate the effectiveness of transfection method in trasfering of foreign genes in zygotes $\boldsymbol{B}$. imbellis. Laboratorium analysis and fishes rearing were conducted at the Research and Depelopment Institute for Ornamental Fish Culture and Research Institute for Freshwater Fish Breeding And Aquaculture, during 6 months. 
B. imbellis broodstock was selected and breeded in a ratio of 1@\&: 1B\&, then performed transfection in the fertilized egg, some eggs was taken for DNA isolation and PCR. Foreign gene for treatment is 1:1 RFP and RFP 3:1, each treatments with 6 replications. Non tranfection treatment without foreign gene was added as control. Observations was done during development of the zygote included hatching rate (HR) and survival rate (SR). Our results showed that for Hatching Rate eggs after transfection did not show a clear pattern of each treatment, but generally have showed no significant difference with non-transgenic controls. PCR results in embryos and larvae showed positive DNA after amplified with approximately $0.6 \mathrm{~kb}$ in size for several replicates. From these results it can be concluded that transfection methods in embryos and larvae showed effective for gene transfer of wild betta (Betta imbellis).

\section{KEYWORDS: wild betta, Betta imbellis, gene transfer, transfection}

\section{PENDAHULUAN}

Ikan cupang alam (Wild betta), Betta imbellis merupakan salah satu ikan hias yang banyak diminati para hobiis. Ikan ini mempunyai ciri-ciri antara lain warna biru tua dengan sirip ventral yang berwarna merah menyala, warna merah pada bagian belakang sirip anal, dan dua garis berwarna biru atau hijau pada tutup insang (Goldstein, 2001). Namun demikian untuk lebih meningkatkan kualitas, baik warna, pertumbuhan maupun daya tahan terhadap penyakit, masih memerlukan sentuhan teknologi untuk mengembangkannya. Sehingga akan lebih banyak meningkatkan jumlah hobiis baik nasional maupun internasional. Salah satu teknologi yang dapat diaplikasikan yaitu dengan transgenesis.

Teknologi transgenesis merupakan suatu teknologi rekayasa gen dengan mengintroduksikan satu atau lebih DNA asing ke organisme uji dengan tujuan untuk memanipulasi genotipenya ke arah yang lebih baik dan selanjutnya dapat ditransmisikan ke keturunannya (Beaumont \& Hoare, 2003 dalam Parenrengi, 2010). Aplikasi transgenesis diharapkan dapat memperbaiki karakterkarakter yang berguna bagi akuakultur seperti peningkatan laju pertumbuhan, perbaikan kualitas daging, peningkatan daya tahan ikan terhadap lingkungan yang ekstrim dan penyakit, serta memperbaiki kualitas warna ikan hias (Gong et al., 2003 dalam Parenrengi, 2010). Pada penelitian ini, untuk meningkatan kualitas warna ikan cupang dilakukan transgenesis dengan menggunakan GFP (Green Fluorescent Protein) dan RFP (Red Fluorescent Protein).

GFP biasanya digunakan untuk kajian tentang efektivitas promoter dan ekspresi gen target. GFP merupakan gen yang mengkodekan protein dan memiliki sifat berpendar hijau (lyengar et al., 1996 dalam Sucipto, 2009). Gen GFP tersebut dapat dengan mudah dideteksi dengan menggunakan mikroskop fluoresens atau melalui analisis ekspresi gen menggunakan teknik RT-PCR. Gen berpendar ini memiliki beberapa kelebihan. GFP umumnya memiliki tingkat toksisitas yang rendah serta dapat diekspresikan sampai level tertinggi pada organisme lain, tanpa mempengaruhi fungsi fisiologisnya. Ketika gen GFP berfusi dengan protein target, GFP akan mempertahankan aktivitas normal dan flouresensinya sehingga lokasi, pergerakan, dan aktivitas lain dari protein target dapat dideteksi. Selain itu, gen GFP tidak memerlukan substrat tambahan dan kofaktor untuk berpendar (Felts et al., 2001 dalam Parenrengi, 2010).

Selain GFP, gen pemendar lain yang sering digunakan dalam kajian ilmiah adalah RFP. Gen RFP diisolasi dari karang genus Discosomasp. Gen ini sangat potensial untuk dikembangkan pada kajian bioteknologi dan biologi sel. RFP dapat berperan sebagai komplemen maupun substitusi gen pemendar hijau GFP dari uburubur.

Dalam proses transgenesis, selain dengan mikroinjeksi maupun elektroforesis, transfeksi merupakan salah satu metode yang dapat diaplikasikan untuk penyisipan gen dengan bantuan vektor virus (Harrison et al., 1998). Metode ini berbasis pada penggunaan lipid sebagai agen untuk membawa gen asing melewati membran sel (Yamano et al., 2011). Reagen transfeksi memungkinkan terjadinya internalisasi DNA asing ke dalam sel oleh karena itu dapat menjadi alternatif metode dalam transfer gen. Reagen transfeksi adalah polimerkation atau lipid yang dapat 
berinteraksi dan berikatan dengan DNA pada permukaannya. Interaksi tersebut memungkinkan terbentuknya kompleks spherical (poliplex dan lipoplex) yang dapat berikatan dengan membran sel target sehingga DNA asing dapat terinternalisasi melalui endositosis dan tidak terdegradasi oleh reaksi enzimatik di dalam sel. Reagen transfeksi memiliki cara kerja yang unik saat memasukkan DNA asing ke dalam sel dengan risiko kerusakan fisik yang lebih kecil pada organisme target. Dengan meminimalisasi kerusakan tersebut, diharapkan derajat penetasan (HR) pada organisme transgenik akan meningkat. Selain itu menurut Felgner et al. (1987), pengembangan metode transfeksi berbasis lipid dapat meningkatkan efisiensi transfer gen dan tidak bersifat toksik pada sel. Hasil penelitian menunjukkan bahwa transfeksi adalah metode yang paling efektif untuk memproduksi udang transgenik jika dibandingkan dengan mikroinjeksi maupun elektroforesis (Sun et al., 2004 dalam Calderon, 2004).

Pelitian ini bertujuan untuk melihat efektivitas metode transfeksi dalam penyisipan gen asing pada zigot ikan cupang alam B. imbellis.

\section{BAHAN DAN METODE}

Gen warna yang dicobakan adalah GFP dan RFP yang telah diintroduksi ke Indonesia. Konstruksi DNA yang digunakan berbentuk plasmid yang dikontrol oleh promoter â-aktin dari ikan medaka dengan panjang fragmen 0,6 kb untuk pmBA GFP (Takagi et al., 1994) dan 4 kb untuk dsRed-N1 (Clontech).

Beberapa pengamatan yang dilakukan dalam penelitian ini antara lain pematangan gonad induk, koleksi telur, transfeksi zigot, derajat penetasan, sintasan, dan deteksi ekspresi gen pemendar serta perkembangan embrio.

\section{Pematangan Gonad Induk}

Induk jantan maupun betina yang akan dipijahkan diseleksi terlebih dahulu. Kriteria seleksi didasarkan pada kondisi fisik ikan yang sehat yaitu pergerakannya aktif, tidak terserang penyakit, warnanya menarik, dan perutnya terlihat membesar sebagai tanda ikan telah mulai matang gonad. Ikan dipelihara di akuarium dengan pemberian pakan secara ad satiation (sampai ikan kenyang). Pemberian pakan dilakukan dua kali sehari, yaitu pada pagi dan sore hari. Pakan yang diberikan berupa bloodworm yang telah diperkaya dengan vitamin E. Sebanyak $100 \mathrm{~g}$ bloodworm ditambahkan dengan $0.240 \mathrm{~g}$ serbuk vitamin $\mathrm{E}$ dan dua kapsul natur-E. Pengkayaan pakan dilakukan untuk mempercepat pematangan gonad.

\section{Koleksi Telur}

Induk jantan dan betina yang telah matang gonad dipijahkan dengan perbandingan $1: 1$ dalam akuarium ukuran $20 \times 15 \times 15 \mathrm{~m}^{3}$ dengan ketinggian air $\pm 14 \mathrm{~cm}$. Telur yang telah dibuahi dikoleksi ke dalam cawan petri kemudian dicuci dengan larutan fisiologis $(\mathrm{NaCl} 0,9 \%)$ dan dilanjutkan pencucian dengan akuades. Dalam penelitian ini ada empat perlakuan pada penelitian ini dengan enam ulangan pada setiap perlakuannya. Disiapkan pula tiga ulangan untuk kelompok kontrol yang tidak diberi perlakuan. Jumlah telur yang digunakan pada masing-masing ulangan berjumlah 50 butir. Setelah dilakukan pencucian, telur yang akan diberi perlakuan dimasukkan ke dalam tube $2 \mathrm{~mL}$ berisi $0,5 \mathrm{~mL}$ air.

\section{Transfeksi Telur}

Transfeksi telur dilakukan pada embriofase 2-64 sel. Langkah pertama yang dilakukan adalah penyiapan larutan transfeksi. Dibuat campuran DNA plasmid pada media $\mathrm{NACl} 0.9 \%$ hingga mencapai konsentrasi akhir 0,01 $\mathrm{gg} /$ $\mu \mathrm{L}$ (1 $\mu \mathrm{g}$ plasmid dalam $100 \mu \mathrm{L}$ media), sebanyak $100 \mu \mathrm{L}$ campuran tersebut dimasukkan ke dalam tube $2 \mathrm{~mL}$ dan diberi label sesuai perlakuan, yaitu GFP 1:1, GFP 3:1, RFP 1:1, dan RFP 3:1. Ditambahkan $1 \mu \mathrm{L}$ reagen ke tube berlabel 1:1 dan $3 \mu \mathrm{L}$ reagen pada tube dengan label 3:1 kemudian campuran reagen:DNA tersebut diinkubasi selama 15 menit pada suhu ruang. Campuran tersebut kemudian dimasukkan ke dalam tube yang berisi telur perlakuan dan diinkubasi selama 2 jam pada suhu ruang. Embrio yang telah diberi perlakuan kemudian dipindah dalam wadah inkubasi sampai menetas. Penggantian air pada wadah pemeliharaan dilakukan tiap 12 jam sekali.

\section{Derajat Penetasan}

Derajat Penetasan adalah persentase jumlah larva yang menetas dibagi dengan jumlah keseluruhan telur yang diberi perlakuan dalam satu ulangan. Penghitungan HR dilakukan untuk mengetahui pengaruh 
perlakuan terhadap persentase penetasan dibandingkan dengan kelompok kontrol. Secara ringkas, derajat penetasan dapat dihitung dengan rumus sebagai berikut:

Derajat penetasan $=\frac{\text { Jumlah telur menetas }}{\text { Jumlah telur dibuahi }} \times 100$

\section{Sintasan}

Selain derajat penetasan, dilakukan juga penghitungan sintasan larva hasil transgenik selama penelitian berlangsung.

\section{Deteksi Ekspresi Gen Pemendar}

Deteksi ekspresi gen pemendar dengan PCR dilakukan dua kali, yaitu pada telur saat fase embrio akhir dan pada larva. Sebelum PCR, dilakukan ekstraksi DNA terlebih dahulu menggunakan kit Puregene (Qiagen) sesuai protokol manual pada kit tersebut. Hasil ekstraksi kemudian dielektroforesis pada gel agarose $1,5 \%$ dengan voltase $65 \mathrm{~V}$, kecepatan $400 \mathrm{mV}$, selama 30-40 menit. DNA yang diperoleh selanjutnya di PCR dengan primer GFP-r: 5'-ACG AAC TCC AGC AT-3' dan GFP-f: 5'GGT CGA GCT GGA CGG CGA CG-3' untuk sampel dengan perlakuan menggunakan GFP. Sampel dengan perlakuan RFP diamplifikasi mengunakan primer dsRed-F : 5' ATG GCC TCC GAG AAC GTC 3' dan dsRed-R : 5' GTC CAG CTT GGC GTC CAC GTA 3' (Purwanti, 2007). Komposisi PCR untuk masing-masing sampel adalah $12,5 \mu \mathrm{L}$ master mix, $0,5 \mu \mathrm{L}$ primer $\mathrm{F}, 0,5$ $\mu \mathrm{L}$ primer $\mathrm{R}$, dan $9 \mu \mathrm{L}$ nuclease free wáter. Setelah dihomogenasi, ditambahkan $2.5 \mu \mathrm{L}$ DNA template ke dalam microtube. Predenaturasi dilakukan pada $95^{\circ} \mathrm{C}$ selama 4 menit sebanyak 1 siklus. Denaturasi dilakukan pada $94^{\circ} \mathrm{C}$ selama 30 detik. Proses annealing dilakukan pada suhu $62^{\circ} \mathrm{C}$ selama 30 detik. Tahap ekstensi awal dilakukan pada suhu $72^{\circ} \mathrm{C}$ selama menit, selanjutnya ekstensi akhir pada suhu $72^{\circ} \mathrm{C}$ selama 7 menit. Denaturasi, annealing, dan ekstensi awal dilakukan sebanyak 35 siklus. Hasil PCR dielektroforesis menggunakan gel agarose $1,5 \%$ pada voltase $65 \mathrm{~V}$ selama 60 menit dan didokumentasikan dengan Gel Doc UV Transilluminator.

\section{HASIL DAN BAHASAN}

\section{Derajat Penetasan}

Pada Tabel 1 dan Gambar 1 menunjukkan bahwa derajat penetasan pasca transfeksi untuk keseluruhan perlakuan baik GFP maupun RFP menunjukkan persentase yang berbedabeda. Hal ini diduga telur yang digunakan dalam perlakuan berasal dari induk yang berbeda, sehingga dimungkinkan mempunyai kualitas telur yang berbeda pula. Sedangkan untuk kontrol pada beberapa ulangan, telur tidak menetas. Hal ini diduga juga adanya kualitas telur yang dihasilkan kurang bagus.

Rata-rata persentase derajat penetasan pasca transfeksi untuk gen RFP lebih tinggi jika dibandingkan dengan menggunakan gen GFP, hal ini disebabkan karena gen RFP mempunyai sifat yang stabil terhadap lingkungan, sehingga telur pasca transfeksi dapat menetas dengan baik. Hal ini sesuai degan pendapat Baird et al. (2000), Gross et al. (2000), Campbell et al. (2002) bahwa gen RFP mempunyai sifat stabil pada perubahan $\mathrm{pH}$ yang ekstrim, denaturasi, dan photobleaching dibandingkan dengan gen GFP. Namun demikian transfer gen GFP dan RFP telah banyak digunakan untuk menghasilkan

Tabel 1. Derajat penetasan telur cupang alam (Betta imbelis) pasca transfeksi (\%)

Table 1. Hatching rate of Betta sp. zygotes after transfection (\%)

\begin{tabular}{|c|c|c|c|c|c|c|c|}
\hline \multirow{2}{*}{$\begin{array}{l}\text { Perlakuan } \\
\text { Treatments }\end{array}$} & \multicolumn{7}{|c|}{$\begin{array}{c}\text { Derajat penetasan telur } \\
\text { Hatching rate (\%) }\end{array}$} \\
\hline & Ulangan 1 & Ulangan 2 & Ulangan 3 & Ulangan 4 & Ulangan 5 & Ulangan 6 & Rata-rata \\
\hline GFP 1:1 & 16 & 2 & 30 & 20 & 52 & 36 & 26.00 \\
\hline GFP $3: 1$ & 26 & 4 & 18 & 36 & 56 & 60 & 33.33 \\
\hline RFP 1:1 & 70 & 50 & 84 & 76 & 64 & 88 & 72.00 \\
\hline RFP $3: 1$ & 88 & 68 & 36 & 56 & 100 & 74 & 70.33 \\
\hline Kontrol & 80 & 72 & - & - & - & - & 76.00 \\
\hline
\end{tabular}


ikan hias yang lebih menarik, contoh ikan zebra berwarna-warni yang dapat dilihat pada kondisi cahaya biasa (Gong et al., 2003 dalam Parenrengi, 2010).

Rendahnya persentase derajat penetasan pasca transfeksi untuk gen GFP diduga selain adanya perbedaan kualitas serta kandungan asam amino dan asam lemak yang terkandung pada telur, juga disebabkan oleh faktor luar seperti temperatur. Menurut Kusrini et al. (2010), bahwa kandungan asam amino dan asam lemak, terutama asam linoleat mempunyai peran dalam pembentukan vitelogenin dari sel telur. Selanjutnya menurut Woynarivich dalam Yustina \& Damawati (2002), bahwa besar kecilnya daya tetas dipengaruhi oleh makan, ukuran ikan dan kondisi lingkungan. Kondisi suhu ruang pendederan pada saat penelitian kurang kondusif sampai $35^{\circ} \mathrm{C}$ sehingga terjadi perubahan yang sangat ekstrim. Hal ini juga diduga sebagai faktor penyebab yang mempengaruhi daya tetas telur. Hal yang sama dikemukakan oleh Effendi (1991), bahwa peningkatan suhu dan tekanan oksigen dapat mempengaruhi daya tetas, sedang suhu air dapat mempengaruhi efisensi perubahan kuning telur menjadi bobot badan embrio ikan pada proses perkembangan. Telur ikan Betta spledens tergolong berukuran sedang, suhu optimal untuk penetasan berkisar antara $26^{\circ} \mathrm{C}$ sampai $28^{\circ} \mathrm{C}$, dengan waktu penetasan sekitar 3 sampai 4 hari.

\section{Ekspresi Gen pada Ikan}

Ekspresi hasil korporasi DNA ke dalam telur melalui transfeksi pada Betta imbellis dapat dilihat pada Tabel 2 dan Gambar 3. Keberhasilan transfer gen GFP dan RFP dapat dibuktikan dengan analisis PCR. Hasil dari PCR embrio dan larva menunjukkan semua positif membawa gen GFP dan RFP. Hal ini memberikan hasil positif sebanyak 45\% untuk semua perlakuan maupun ulangan. Pengecekan ekspresi berikutnya dilakukan setelah ikan berumur sekitar 3 minggu (dapat dipotong siripnya). Individu yang positif tersebut selanjutnya akan dilakukan analisis RNA untuk mengetahui ekspresi GFP dan RFP pada gonad setelah ikan dewasa.

Hasil PCR pada telur dan larva menunjukkan bahwa tingkat keberhasilan yang optimal ditunjukkan pada transfeksi GFP, sedangkan trafeksi RFP pada telur dan larva belum memperlihatkan hasil yang optimal (gen

Tabel 2. Hasil PCR pada telur dan larva ikan cupang setelah perlakuan

Table 2. $\quad P C R$ result in zygotes and larvae after treatments

\begin{tabular}{|c|c|c|c|c|c|}
\hline $\begin{array}{l}\text { Kode } \\
\text { Code }\end{array}$ & $\begin{array}{l}\text { Perlakuan } \\
\text { Treat ment }\end{array}$ & PCR & $\begin{array}{l}\text { Kode } \\
\text { Code }\end{array}$ & $\begin{array}{l}\text { Perlakuan } \\
\text { Treatment }\end{array}$ & PCR \\
\hline $\mathrm{Al}$ & GFP 1:1 (1) & + & $1 \mathrm{~A}$ & RFP 1:1 (1) & + \\
\hline $\mathrm{Bl}$ & GFP 1:1 (2) & + & $2 \mathrm{~A}$ & RFP 1:1 (2) & - \\
\hline $\mathrm{Cl}$ & GFP 1:1 (3) & + & $3 \mathrm{~A}$ & RFP 1:1 (3) & - \\
\hline D1 & GFP 1:1 (4) & + & $4 \mathrm{~A}$ & RFP 1:1 (4) & + \\
\hline $\mathrm{El}$ & GFP 1:1 (5) & + & $5 \mathrm{~A}$ & RFP 1:1 (5) & - \\
\hline $\mathrm{Fl}$ & GFP 1:1 (6) & + & $6 \mathrm{~A}$ & RFP 1:1 (6) & + \\
\hline $\mathrm{A} 2$ & GFP 3:1 (1) & + & $1 \mathrm{~B}$ & RFP 3:1 (1) & - \\
\hline B2 & GFP 3:1 (2) & + & $2 \mathrm{~B}$ & RFP 3:1 (2) & - \\
\hline C2 & GFP 3: 1 (3) & + & $3 B$ & RFP 3: 1 (3) & - \\
\hline D2 & GFP 3: 1 (4) & + & $4 B$ & RFP 3: 1 (4) & + \\
\hline E2 & GFP 3:1 (5) & + & $5 B$ & RFP 3:1 (5) & - \\
\hline $\mathrm{F} 2$ & GFP 3: 1 (6) & + & $6 \mathrm{~B}$ & RFP 3:1 (6) & + \\
\hline
\end{tabular}

Keterangan:

$\begin{array}{ll}(+) & : \text { gen terdeteksi } \\ (-) & : \text { gen tidak terdeteksi }\end{array}$ 
terdeteksi hanya pada beberapa perlakuan). Hal ini sesuai pendapat Purwanti (2007), bahwa tingkat keberhasilan dan ekspresi GFP pada ikan mas Cyprinus carpio dan ikan lele diperoleh hasil yang tinggi.

Berdasarkan hasil PCR pada telur dan larva menunjukkan bahwa pada semua perlakuan dan ulangan dengan GFP baik 1:1 maupun 3:1 menunjukkan (+) atau gen berhasil terdeteksi (Tabel 2), Sedangkan untuk perlakuan RFP 1:1, gen berhasil terdeteksi hanya pada 3 ulangan, dan terdeteksi juga pada 2 ulangan untuk gen RFP 3:1. Hal ini juga dapat dibuktikan dengan munculnya pita (band) hasil elektroforesis yaitu pada ukuran pita DNA sekitar $0,6 \mathrm{~kb}$ yang ditemukan pada telur dan embrio (Gambar 1) dan larva (Gambar 2).
Kelompok non transgenik pun dapat teramplifikasi dengan ukuran DNA yang sama. Menurut Sambrook \& Russel (2001), munculnya pita DNA pada kontrol non transgenik dapat disebabkan karena peralatan yang digunakan dengan template DNA. Seharusnya konstruksi plasmid didesian dari ikan cupang alam sendiri (all fish gene construct), sehingga akan diperoleh primer yang spesifik, seperti yang dilakukan Parenrengi (2010) dengan menggunakan all-shrimp gene construct untuk trangeneisis pada udang windu. Namun demikian hal ini membutuhkan waktu yang cukup lama dan tidak mungkin dilakukan dalam penelitian ini. Untuk melihat spesifik atau tidaknya primer yang digunakan, maka dilakukan PCR pada sirip induk $B$. Imbellis dan pada genom ikan mas (Cyprinus carpio) (Gambar 3).

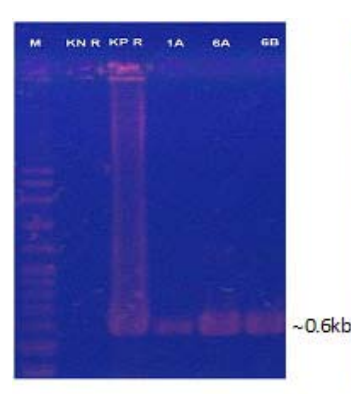

a

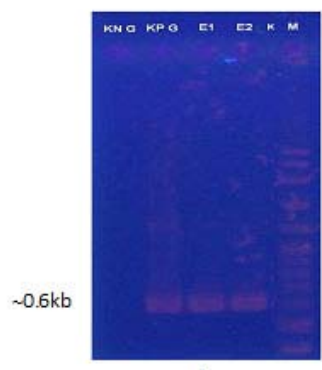

d

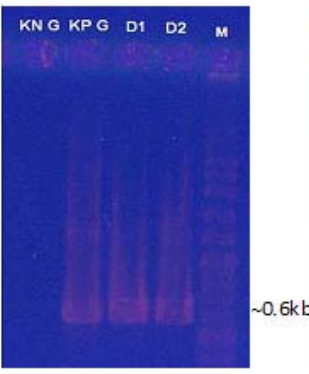

b

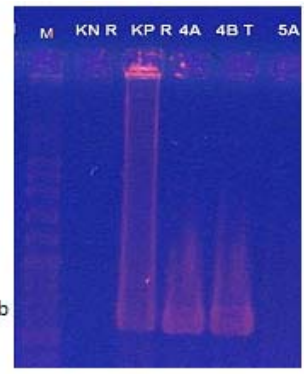

c

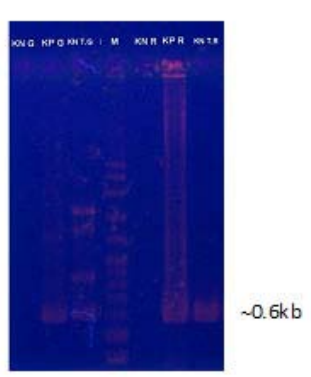

e

keterangan:M= marker 100 bp DNA ladder, $\mathrm{KN} \mathrm{G}=$ kontrol negatif GFP, KN R= kontrol negatif RFP, KP G=kontrol positif GFP, KP R= kontrol positif RFP, KN TG= embrio non transgenik untuk kontrol GFP, KN TR= embrio non transgenik untuk kontrol RFP)

note:-M=100 bp DNA ladder, KN G= negative control of GFP, $K N R=$ negative control of RFP, KP G= positive control of GFP, KP R= positive control of RFP, $K N T G=$ negative control of GFP from non transgenic group, $K N T R=$ negative control of RFP from non transgenic group)

Gambar 1. Hasil PCR telur dan embrio Betta sp.

Figure 1. PCR of eggs and embryo results 


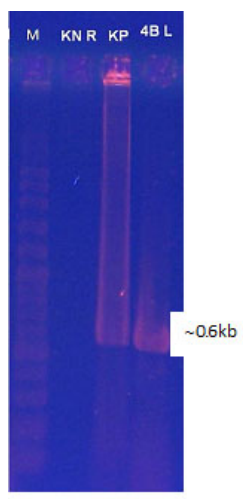

a

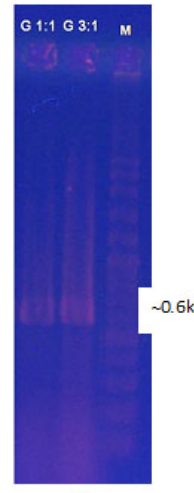

b

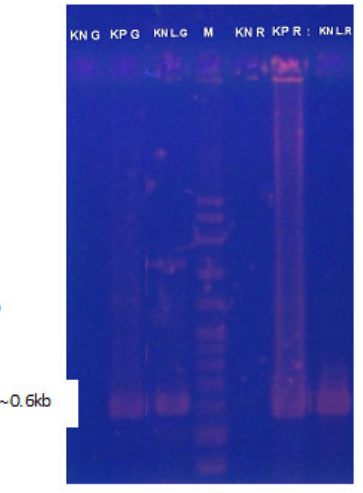

keterangan: $\mathrm{M}=$ marker 100 bpDNA ladder, $\mathrm{KN} \mathrm{G}=$ kontrol negatif GFP, KN R= kontrol negatif RFP, KP G=kontrol positif GFP, KP $\mathrm{R}=$ kontrol positif RFP, KN LG=larva non transgenik untuk kontrol GFP, KN LR=larva non transgenik untuk kontrol RFP) note: $M=100 \mathrm{bp} D N A$ ladder, $K N G=$ negative control of GFP, $K N R=$ negative control of RFP, KP G= positive control of GFP, KP R= positive control of RFP, KN $L G=$ negative control for GFP from larvae of non transgenic group, $K N L R=$ negative control for RFP from larvae of non transgenic group)

Gambar 2. Hasil PCR larva Betta imbellis

Figure 2. PCR of larvae Betta imbellis results

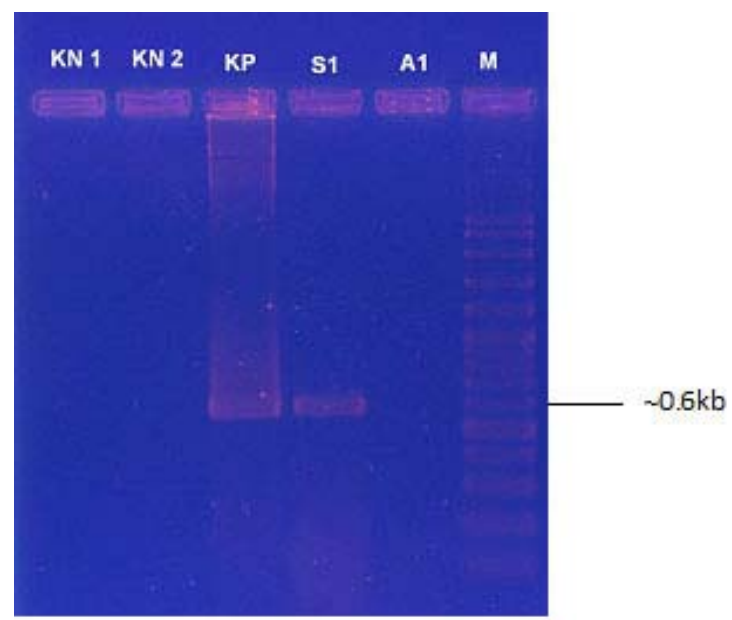

keterangan: $\mathrm{M}=100 \mathrm{bp}$ DNA ladder, $\mathrm{KN}=$ kontrol negatif, $\mathrm{KP}=$ kontrol positif, $\mathrm{S} 1=\operatorname{sirip} B$.imbellis, $\mathrm{A} 1=$ genom $C$. carpio.

note: $M=100$ bp DNA ladder, KN1 \& KN 2=negative control, $K P=$ positive control, $S 1=$ broodstock's fin of Betta sp., Al= genom of C. carpio.

Gambar 4. Hasil PCR pada gel agarose 1.5\%

Figure 4. PCR results in $1.5 \%$ agarose gel 
Tabel 3. Jumlah sintasan hasil penyisipan gen warna RFP dan GFP

Table 3. Survival Rate resulted form introduced RFP gen and GFP

\begin{tabular}{cc}
\hline $\begin{array}{c}\text { Perlakuan } \\
\text { Treat ments }\end{array}$ & $\begin{array}{c}\text { Sintasan } \\
\text { Survival rate }\end{array}$ \\
\hline RFP $1: 1$ & 4 \\
RFP $1: 1$ & 24 \\
RFP $1: 1$ & 30 \\
RFP $3: 1$ & 10 \\
RFP $3: 1$ & 21 \\
RFP $3: 1$ & 6 \\
GFP 1:1 1 & 13 \\
GFP 1:1 & 8 \\
GFP 1:1 & 17 \\
GFP $3: 1$ & 17 \\
GFP $3: 1$ & 39 \\
GFP $3: 1$ & 3 \\
Kontrol negative & 3 \\
Kontrol posistif (RFP) & 2 \\
Kontrol negatif (CFP) & 1 \\
\hline
\end{tabular}

Konfirmasi PCR menunjukkan bahwa pita DNA hanya muncul pada kontrol positif dan sampel sirip, akan tetapi tidak muncul pada tiga sampel lainnya. Dalam hal ini, hasil PCR yang belum konsisten dapat disebabkan oleh beberapa faktor. Kondisi PCR yang belum optimal juga dapat menyebabkan hal tersebut terjadi. Kontaminasi pada gel agarose atau pada saat elektroforesis adalah faktor lain yang diduga menjadi penyebabnya.

\section{Sintasan Larva}

Penghitungan sintasan larva hasil transgenik dilakukan selama pemeliharaan. Namun demikian selama pemeliharaan banyak juga mengalami kematian, demikian juga untuk ikan kontrol sintasan cukup rendah (Tabel 3).

Tabel 3 di atas menunjukkan bahwa sintasan dari hasil perlakuan yang berbeda pada penyisipan gen RFP dan gen GFP menunjukan pola yang tidak jelas. Hal ini diduga sintasan yang ada bukan semata-mata pengaruh dari perlakuan, tetapi ada faktor lain selama embriogenesis maupun setelah ikan menetas, baik dari lingkungan ataupun kualitas telur ikan itu sendiri.

Hasil penelitian menunjukkan adanya mortalitas pada larva. Mortalitas pada larva diduga disebabkan selain habisnya cadangan makanan berupa kuning telur, juga makanan alami yang terdapat di dalam media hidupnya tidak sesuai baik jenis, ukuran maupun jumlahnya.

\section{KESIMPULAN DAN SARAN}

Hasil yang diperoleh menunjukan bahwa metode transfeksi dalam penyisipan gen asing pada zigot $B$. imbellis terbukti efektif. Hal ini dapat dibuktikan dengan teramplifikasinya gen GFP dan RFP positif berdasarkan cek PCR. Namun demikian, masih perlu dilakukan uji RT PCR terhadap calon induk FO (untuk meyakinkan keberhasilan gen GFP dan RFP yang ditransfer tersebut dalam gonad, dan nantinya apakah diturunkan pada generasi berikutnya).

Metode transfeksi berpotensi untuk dikembangkan dalam transgenesis karena 
reagen yang digunakan dalam penelitian ini tidak bersifat toksik pada individu target. Selain itu, untuk metode transfeksi tersebut lebih mudah untuk diaplikasikan terhadap ikanikan hias berukuran kecil, yang pada umumnya sulit dilakukan pemijahan buatan.

\section{UCAPAN TERIMA KASIH}

Penelitian ini dibiayai oleh DIPA tahun anggaran 2011 Balai Penelitian Dan Pengembangan Budidaya Ikan Hias. Tim peneliti mengucapkan terima kasih kepada Kepala Balai Penelitian dan Pengempangan Budidaya Ikan Hias, Kepala Balai Penelitian Pemuliaan Ikan, Sukamandi beserta staf peneliti di laboratorium genetik yang telah banyak membantu dalam penelitian ini serta memberikan keleluasaan menggunakan semua fasilitas yang ada. Ucapan terima kasih juga disampaikan kepada Dr. Alimuddin dan Dwiatmi Narwanti yang banyak membantu kelancaran dalam pelaksanaan penelitian ini.

\section{DAFTAR PUSTAKA}

Baird, G.S., Zacharias, D.A., \& Tsien, R.Y. 2000. Biochemistry, mutagenesis, and oligomerization of DsRed, a red fluorescent protein from coral. PNAS 97: 11984-11989.

Calderon, F.R.O. 2004. Transfection reagentmediated gene transfer for the pacific white shrimp Litopenaeus vannamei [Tesis]. University of Hawaii: Hawaii, $57 \mathrm{hlm}$.

Campbell, R.E., Oded T., Palmer, A.E., Steinbach, P.A., Baird, G.S., Zacharias, D.A., \& Tsien, R.Y. 2002. A monomeric red fluorescent protein, PNAS 99: 7877-7882.

Effendi, M.I. 1991. Biologi Perikanan: Jakarta. Yayasan Pustaka Nusatama, p. 48-67.

Felgner, P.L., Gadek T.R., Holm, M., Roman, R., Chan, H.W., Wenz, M., Northorp, J.P., Ringold, G.M., \& Danielsen, M. 1987. Lipofection: a highly efficient, lipid-mediated DNA-transfection procedure. Proc. Natl. Acad. Sci. USA, 84: 7413-7417.

Goldstein, R.J. 2001. Bettas: Everything About Purchase, Nutrition, Feeding, and Health Care. New York: Barron's Educational se- ries, Inc., $112 \mathrm{hlm}$.

Gross, L.A., Baird, G.S., Hoffman, R.C., Baldridge, K.K., \& Tsien, R.Y. 2000. The structure of the chromophore within DsRed, a red fluorescent protein from coral. PNAS, 11990 11995.

Harrison, R.L., Byrne, B.J., \& Tung, L. 1998. Electroporation-mediatedgene transfer in cardiac tissue. FEBS Letters, 435: 1-5.

Kusrini, E., Sudarto, Prasetio, A.B., Kusumah, R.V., \& Cindelaras, S. 2010. Keragaan Hasil Persilangan Ikan Cupang Hias Betta splendens Sebagai Studi Pendahuluan Program Pemuliaan Ikan Hias. (un-published), $15 \mathrm{hlm}$.

Nagy, A., Bercesenyi, M., \& Csenyi, V. 1981. Sex Reversal In Corp Cyprinus carpio by Oral administration of mettytestoteron. Canadian Journal of Fisheries \& Aquatic Science, 38: 725-728.

Parenrengi, A. 2010. Peningkatan resistensi udang windu Penaeus monodon terhadap penyakit White Spot Syndrome Virus melalui transfer gen Penaeus monodon antiviral [Disertasi]. Sekolah Pascasarjana Institut Pertanian Bogor: Bogor, $98 \mathrm{hlm}$.

Purwanti, L.I. 2007. Uji aktivitas promoter betaActin ikan medaka (Oryzuas latipes) pada ikan mas (Cyprinus carpio) (Skripsi). Bogor. Fakultas Perikanan dan Kelautan, Intitut Pertanian Bogor, $43 \mathrm{hlm}$.

Sambrook, J. \& Russel, D.W. 2001. Molecular Cloning: a Laboratory Manual $3^{\text {rd }}$ ed. NewYork: Cold Spring Harbor Laboratory Press, 2,344 pp.

Syandri, H. 1996. Aspek reproduksi Ikan bilih Mystacolecsus padangensis. Disertasi Program Pasca Sarjana Fakultas Perikanan. Bogor: Institut pertanian Bogor, $137 \mathrm{hlm}$.

Sucipto, A. 2009. Efektifitas promoter keratin, Heat shock, dan ${ }^{2}$-aktin pada transgenesis ikan nila (Orechromis niloticus), $49 \mathrm{hlm}$.

Yamano, S., et al. 2011 . Modified Tat peptide with cationic lipid enhances gene transfection efficiency via temperature-dependent and caveolae-mediated endocytosis. Journal of Controlled Release, 152: 278-285. 